\title{
ӨНӨӨГИЙН МОНГОЛ ОРНЫ УРГАМЛЫН АЙМГИЙН ЗУЙЛИЙН БҮРДЭЛ, ОЛОН ЯНЗ БАЙДАЛ
}

\author{
М.Ургамал, О.Энхтуяа, Н.Хэрлэнчимэг, Э.Энхжаргал \\ Ц.Бөхчулуун, Г.Бүрэнбаатар, С.Жавхлан \\ Ерөнхий болон сорильнн биологийн хүрээлэнгийн Ангилалзүйн лаборатори, \\ Шинжлэх ухааны Академи, Монгол улс \\ Цахим шуудан: urgamal@botany.mas.ac.mn
}

\section{Хураангуй}

Өдгөө Монгол орны ургамлын аймгийн олн янз байдалд 19 хүрээнд хамаарах 39 ангийн 116 багийн 392 овогт хамаарах 1522 төрөлд багтах 7315 зүйл, дэд зүйл бүртгэгджээ. Үүнд 56 овгийн 156 төрлийн 574 зүйл, дэд зүйл дээд мөөг; 87 овгийн 268 төрлийн 2003 зүйл, дэд зүйл замаг; 63 овгийн 207 төрлийн 1031 зүйл, дэд зүйл хаг; 74 овгийн 208 төрлийн 580 зүйл, дэд зүйл хөвд; 112 овгийн 683 төрлийн 3127 зүйл, дэд зүйл гуурст ургамал тус тус багтана.

Монгол орны гуурст ургамлын аймагт унаган ургамал 153 зүйл (4.89\%), завсрын унаган 458 зүйл (14.64\%), нэн ховор 133 зүйл (4.25\%), ховор 356 зүйл (11.38\%), харь ургамал 35 зүйл (1.11\%), хөл газрын ургамал 438 зүйл (14.0\%), усны ургамал 143 зүйл (4.57\%), үлдэи (үлдвэр) ургамал 70 зүйл (0.99\%), зэрлэгшиж буй таримал 47 зүйл (1.50\%), Улаан номонд (2013) орсон 135 зүйл (4.31\%), Улаан дансанд (2011) орсон 148 зүйл (4.73\%), CITES-ийн хавсралтанд орсон 8 зүйл (0.25\%) тус тус ургана.

Түлхүур уг: Мөөг, замаг, хаг, хөвд, гуурст ургамал, олон янз байдал, Монгол

\section{ОРШИЛ}

Монгол орны доод ба спор бүхий дээд ургамлын аймгийн судалгаа 1970-аад оноос эхэлсэн түүхтэй. Монгол орны замгийн зүйлийн бүрдлийг илрүүлэх судалгааг 1960-аад оноос А.Дулмаа, Ө.Цогт, Н.И.Дорофеюк, Н.Өлзийхутаг, Д.Цэцэгмаа, сүүлд Н.Сонинхишиг, Ц.Бөхчулуун нарын судлаачид; мөөгийн судалгааг 1936 онд Н.Л. Десяткин эхлүүлж, 1961 оноос хойш Т.Пунцаг, Г.Уранчимэг, Б.Алтанцэцэг, Н.Хэрлэнчимэг нар үргэлжлүүлэн ангилалзүйн судалгааг хийсээр ирсэн. Хагийн судалгаа 1905 оноос эхтэй бөгөөд түүнээс хойш О.Клемент, Р.Шуберт, Ц.Жамсран, Н.Өлзийхутаг, Н.С.Голубкова, Ө.Цогт, Л.Г.Бязров нар дагнан судалж их хэмжээний цуглуулга бүрдүүлсэн ба эдүгээ О.Энхтуяа, С.Жавхлан нарын судлаачид үргэлжлүүлэн судалгаaг гүйцэтгэж байна. Монгол орны хөвдийн зүйлийн бүрдлийг тогтоох судалгаа тэртээ 1902 онд эхэлснээс хойш Ц.Даваажамц, Ө.Цогт, Н.Өлзийхутаг, О.Шуберт, А.Л.Абрамова, И.И.Абрамов, Ц.Цэгмэд, Э.Энхжаргал зэрэг судлаачид ихээхэн хувь нэмрээ оруулжээ. Ингээд Монгол орны доод ба үндэсгүй дээд ургамлын аймгийн зүйлийн бүрдлийг хожим Н.Өлзийхутаг (1989) өөрийн бүтээлдээ 11 хүрээний 184 овгийн 592 төрөлд багтах 2664 зүйлийг багтаан оруулсан байдаг $[1,2,7]$.

Монгол орны гуурст ургамлын аймгийн судалгааг анх 1859 онд Оросын эрдэмтэн К.И.Максимовичийн “Амурын ургамлын аймгийн дээжис” (1859) хэмээх өөрийн бүтээлийнхээ хавсралтанд 489 зүйлийг 
багтаасан Монголын ургамлын анхны жагсаалтыг нийтлүүлж, мөн Траутфеттер Монголын 529 зүйл ургамлыг багтаасан нэмэлт жагсаалтыг гаргаснаар эхэлсэн юм $[2,6,7,9]$.

Гуурст ургамлын анхны бүртгэл бичгийг Оросын нэрт эрдэмтэн В.И.Грубов 1955 онд гаргасан бөгөөд уг бүтээлдээ Монгол орны ургамлын аймгийн судалгааны түүх, онцлог, түүхэн хөгжил, мужлалыг нэгтгэн дүгнэсэн байна. Мөн тэрээр үүнээс нэлээд хойно буюу 1982 онд “Монгол орны гуурст дээд ургамал таних бичиг” номондоо 103 овгийн 600 төрлийн 2268 зүйл гуурст ургамал оруулсан юм. Н.Өлзийхутаг "Монгол орны ургамлын аймгийн тойм (1989)" бүтээлдээ Монголын ургамлын

\section{СУДАЛГААНЫ МАТЕРИАЛ, АРГА ЗУЙ}

Судалгааны материал нь Монголын Шинжлэх Ухааны Академийн харъяа Ерөнхий болон Сорилын Биологийн хүрээлэнгийн Ургамал судлалын салбарын Ургамлын сан (UBA)-д хадгалагдаж буй одоогоос 200-гаад жилийн тэртээгээ цуглуулсан мөөгийн 3900, замгийн 4600, хагийн 13500, хөвдийн 21300, гуурст аймагт 122 овгийн 625 төрөлд хамаарах 2443 зүйл, Оросын эрдэмтэн И.А.Губанов "Гадаад Монголын ургамлын аймгийн конспект (1996)" номондоо Монголын ургамлын аймагт 128 овгийн 662 төрлийн 2823 зүйл гуурст ургамлыг бүртгэсэн байдаг [2-5, 6, 8].

Сүүлд 2014 онд үндэсний эрдэмтдийн (М.Ургамал, Б.Оюунцэцэг, Д.Нямбаяр, Ч.Дуламсүрэн) хамтын бүтээл болох “Монгол орны гуурст ургамлын бүртгэл (Conspectus of the vascular plants of Mongolia, 2014)” хэмээх бүтээлдээ өдгөө Монгол оронд 112 овогт хамаарах 683 төрлийн 3127 зүйл, дэд зүйл гуурст ургамлыг бүртгэн оруулсан байна [8].

ургамлын 82600, нийтдээ 126,000 орчим хуудас; мөн МУИС-ийн Биологийн тэнхимийн Ургамлын сан (UBU)-д буй нийт 12,500 хуудас ургамлын биет цуглуулгуудад тулгуурласан бөгөөд холбогдох мэргэжилтэн судлаачдын ном бүтээл, эрдэм шинжилгээний тайлан, өгүүллүүдээс тоон мэдээ баримтыг шүүн авлаа [2-4].

\section{СУДАЛГААНЫ ҮР ДУН}

Өнөөгийн байдлаар, Монгол орны ургамлын аймаг, түүний олон янз байдалд 19 хүрээнд хамаарах 39 ангийн 116 багийн 392 овогт хамаарах 1522 төрөлд багтах 7315 зүйл, дэд зүйл бүртгэгджээ. Үүнд 56 овгийн 156 төрлийн 574 зүйл, дэд зүйл дээд мөөг;
87 овгийн 268 төрлийн 2003 зүйл, дэд зүйл замаг; 63 овгийн 207 төрлийн 1031 зүйл, дэд зүйл хаг [1]; 74 овгийн 208 төрлийн 580 зүйл, дэд зүйл хөвд; 112 овгийн 683 төрлийн 3127 зүйл, дэд зүйл гуурст ургамал багтана (Хүснэгт 1).

Хүснэгт 1. Монгол орны ургамльн аймгийн бүрэлдэхүҮн, түҮний зүйлийн бүрдэл, эзлэх хувь

\begin{tabular}{|c|c|c|c|c|c|c|c|}
\hline Бүлгийн нэр & ХУрээ & Анги & Баг & Овог & Төрөл & Зүйл, дэд зүйл & Эзлэх хувь \\
\hline 1. Мөөг (дээд) & 2 & 7 & 20 & 56 & 156 & 574 & 7.85 \\
\hline 2. Замаг & 10 & 13 & 39 & 87 & 268 & 2003 & 27.38 \\
\hline 3. Xaz & 1 & 3 & 12 & 63 & 207 & 1031 & 14.09 \\
\hline \multirow[t]{2}{*}{ 4. Хөвд } & 1 & 2 & 6 & 74 & 208 & 580 & 7.93 \\
\hline & 14 & 25 & 77 & 280 & 839 & 4188 & 57.82 \\
\hline 5. Гуурст ургамал & 5 & 14 & 39 & 112 & 683 & 3127 & 42.75 \\
\hline нийт & 19 & 39 & 116 & 392 & 1522 & 7315 & 100.0 \\
\hline
\end{tabular}


Монгол оронд өдгөө 56 овгийн 156 төрөлд багтах 574 зүйл, дэд зүйл дээд мөөг тэмдэглэгдсэн бөгөөд Ascomycota (12 зүйл) болон Basidiomycota (562 зүйл) хэмээх 2 том хүрээнд хуваагддаг (хүснэгт 2). Доод ба спор бүхий дээд ургамал:
Монгол орны ургамлын аймгийн олон янз байдал нь доод ба спор бүхий дээд ургамал (нийт 4188 зүйлтэй) болон гуурст ургамал (нийт 3127 зүйлтэй) гэж 2 үндсэн том бүлэгт хуваагдах ба 58/42 хувийн харьцаатай юм.

ХУснэгт 2. Монгол орны дээд мөөгийн зүйлийн бүрдэл, эзлэх хувь

\begin{tabular}{ccccccc}
\hline Хурээний нэр & Анги & Баг & Овог & Төрөл & Зүйл, дэд зүйл & Эзлэх хувь \\
1. Ascoтусота & 3 & 4 & 6 & 10 & 12 & 2.09 \\
2. Basidiomycota & 4 & 16 & 50 & 146 & 562 & 97.91 \\
\hline нийт & 7 & 20 & 56 & 156 & 574 & 100.0 \\
\hline
\end{tabular}

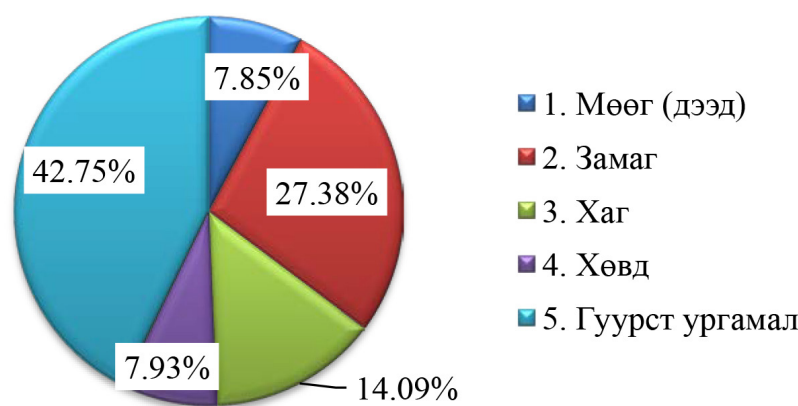

Зураг 1. Монгол орны ургамльн аймгийн олон янз байдал, тэдгээрийн эзлэх хувь

Монгол орны доод ба спор бүхий ба зүйлийн бүрдэл доорх хүснэгтүүдээ дээд ургамал болох мөөг (дээд), замаг, тодорхой харагдана (хүснэгт 3-6).

хаг, хөвдийн томоохон 10 овог, төрөл

Хүснэгт 3. Монгол орны дээд мөөгийн 10 том овог, төрлийн зүйлийн бүрдэл, эзлэх хувь

\begin{tabular}{|c|c|c|c|c|c|c|}
\hline Овгийн нэр & $\begin{array}{c}\text { Төрлийн } \\
\text { тоо }\end{array}$ & $\begin{array}{c}\text { Зуйлийн } \\
\text { тоо }\end{array}$ & $\begin{array}{c}\text { Эзлэх } \\
\text { хувь }\end{array}$ & Төрлийн нэр & $\begin{array}{c}\text { Зүйлийн } \\
\text { тоо }\end{array}$ & $\begin{array}{c}\text { Эзлэх } \\
\text { хувь }\end{array}$ \\
\hline 1. Russulaceae & 2 & 39 & 6.8 & 1. Russula & 22 & 3.8 \\
\hline 2. Agaricaceae & 14 & 38 & 6.6 & 2. Lactarius & 17 & 3.0 \\
\hline 3. richolomataceae & 13 & 34 & 5.9 & 3. Cortinarius & 17 & 3.0 \\
\hline 4. Polyporaceae & 15 & 27 & 4.7 & 4. Suillus & 9 & 1.6 \\
\hline 5. Strophariaceae & 8 & 21 & 3.7 & 5. Tricholoma & 9 & 1.6 \\
\hline 6. Cortinariaceae & 2 & 18 & 3.1 & 6. Clitocybe & 9 & 1.6 \\
\hline 7. Hygrophoraceae & 5 & 15 & 2.6 & 7. Hygrocybe & 7 & 1.2 \\
\hline 8. Marasmiaceae & 6 & 14 & 2.4 & 8. Agaricus & 7 & 1.2 \\
\hline 9. Suillaceae & 2 & 12 & 2.1 & 9. Pleurotus & 6 & 1.0 \\
\hline 10. Hymenochaetaceae & 6 & 11 & 1.9 & 10. Amanita & 6 & 1.0 \\
\hline
\end{tabular}


Хүснэгт 4. Монгол орны замгийн 10 том овог, төрлийн зүйлийн бүрдэл, эзлэх хувь

\begin{tabular}{|c|c|c|c|c|c|c|}
\hline Овгийн нэр & $\begin{array}{c}\text { Төрлийн } \\
\text { тоо }\end{array}$ & $\begin{array}{c}\text { Зүйлийн } \\
\text { тоо }\end{array}$ & $\begin{array}{c}\text { Эзлэх } \\
\text { хувь }\end{array}$ & Төрлийн нэр & $\begin{array}{c}\text { Зүйлийн } \\
\text { тоо }\end{array}$ & $\begin{array}{c}\text { Эзлэх } \\
x у в ь\end{array}$ \\
\hline 1. Naviculaceae & 19 & 156 & 7.8 & 1. Navicula & 127 & 6.3 \\
\hline 2. Pinnulariaceae & 4 & 153 & 7.6 & 2. Pinnularia & 121 & 6.0 \\
\hline 3. Bacillariaceae & 4 & 149 & 7.4 & 3. Nitzschia & 98 & 4.9 \\
\hline 4. Desmidiaceae & 19 & 125 & 6.2 & 4. Gomphonema & 79 & 3.9 \\
\hline 5. Fragilariaceae & 15 & 114 & 5.7 & 5. Eunotia & 61 & 3.0 \\
\hline 6. Gomphonemataceae & 4 & 105 & 5.2 & 6. Cymbella & 51 & 2.5 \\
\hline 7. Cymbellaceae & 7 & 102 & 5.1 & 7. Cosmarium & 45 & 2.2 \\
\hline 8. Pleurosigmataceae & 4 & 85 & 4.2 & 8. Stauroneis & 42 & 2.1 \\
\hline 9. Eunotiaceae & 1 & 61 & 3.0 & 9. Surirella & 38 & 1.9 \\
\hline 10. Phormidiaceae & 8 & 61 & 3.0 & 10. Phormidium & 38 & 1.9 \\
\hline
\end{tabular}

Хүснэгт 5. Монгол орны хагийн 10 том овог, төрлийн зүйлийн бүрдэл, эзлэх хувь

\begin{tabular}{|c|c|c|c|c|c|c|}
\hline Овгийн нэр & $\begin{array}{c}\text { Төрлийн } \\
\text { тоо }\end{array}$ & $\begin{array}{c}\text { Зүйлийн } \\
\text { тоо }\end{array}$ & $\begin{array}{c}\text { Эзлэх } \\
x у в ь\end{array}$ & Төрлийн нэр & $\begin{array}{c}\text { Зүйлийн } \\
\text { тоо }\end{array}$ & $\begin{array}{c}\text { Эзлэх } \\
\text { хувь } \\
\end{array}$ \\
\hline 1. Parmeliaceae & 34 & 176 & 17.1 & 1. Cladonia & 57 & 5.5 \\
\hline 2. Physciaceae & 11 & 95 & 9.2 & 2. Lecanora & 48 & 4.7 \\
\hline 3. Lecanoraceae & 9 & 81 & 7.9 & 3. Peltigera & 25 & 2.4 \\
\hline 4. Verrucariaceae & 11 & 70 & 6.8 & 4. Melanelia & 19 & 1.8 \\
\hline 5. Acarosporaceae & 4 & 58 & 5.6 & 5. Usnea & 15 & 1.5 \\
\hline 6. Teloschictaceae & 4 & 49 & 4.8 & 6. Hypogymnia & 11 & 1.1 \\
\hline 7. Peltigeraceae & 3 & 45 & 4.4 & 7. Xanthoparmelia & 10 & 1.0 \\
\hline 8. Collemataceae & 2 & 32 & 3.1 & 8. Evernia & 7 & 0.7 \\
\hline 9. Bacidiaceae & 6 & 24 & 2.3 & 9. Parmelia & 7 & 0.7 \\
\hline 10. Lichenaceae & 13 & 21 & 2.0 & 10. Flavopunctelia & 2 & 0.2 \\
\hline
\end{tabular}

Хүснэгт 6. Монгол орны хөвдийн 10 том овог, төрлийн зүйлийн бүрдэл, эзлэх хувь

\begin{tabular}{|c|c|c|c|c|c|c|}
\hline Овгийн нэр & $\begin{array}{c}\text { Төрлийн } \\
\text { тоо }\end{array}$ & $\begin{array}{c}\text { Зүйлийн } \\
\text { тоо }\end{array}$ & $\begin{array}{l}\text { Эзлэх } \\
\text { хувь }\end{array}$ & Төрлийн нэр & $\begin{array}{c}\text { Зүйлийн } \\
\text { тоо }\end{array}$ & $\begin{array}{c}\text { Эзлэх } \\
\text { хувь }\end{array}$ \\
\hline 1. Pottiaceae & 25 & 82 & 14.1 & 1. Bryum & 31 & 5.3 \\
\hline 2. Dicranaceae & 16 & 47 & 8.1 & 2. Didymodon & 22 & 3.8 \\
\hline 3. Grimmiaceae & 6 & 37 & 6.4 & 3. Grimmia & 18 & 3.1 \\
\hline 4. Bryaceae & 4 & 36 & 6.2 & 4. Sphagnum & 17 & 2.9 \\
\hline 5. Amblystegiaceae & 13 & 25 & 4.3 & 5. Dicranum & 16 & 2.8 \\
\hline 6. Lophaziaceae & 8 & 23 & 4.0 & 6. Scapania & 13 & 2.2 \\
\hline 7. Hypnaceae & 11 & 22 & 3.8 & 7. Pohlia & 13 & 2.2 \\
\hline 8. Brachythiceae & 7 & 20 & 3.4 & 8. Нурпит & 11 & 1.9 \\
\hline 9. Sphagnaceae & 1 & 17 & 2.9 & 9. Brachythecium & 11 & 1.9 \\
\hline 10. Mniaceae & 6 & 17 & 2.9 & 10. Syntrichia & 10 & 1.7 \\
\hline
\end{tabular}




\section{Гуурст ургамал:}

Өдгөө Монгол орны ургамлын аймагт 3 дэд аймгийн (Ойм, Нүцгэн үртэн, Далд үртэн) 5 хүрээнд багтах 14 ангийн 39 багийн 112 овогт хамаарах 683 төрлийн 3127 зүйл, дэд зүйл (131 дэд зүйл, 32 вариац) гуурст дээд ургамал бүртгэгдээд байна (хүснэгт 7).

Хүснэгт 7. Монгол орны гуурст ургамльен зүйлийн бүрдэл, эзлэх хувь (Urgamal et al. 2014)

\begin{tabular}{|c|c|c|c|c|c|c|c|}
\hline \multirow{2}{*}{ Дэд аймаг } & ХУрээ & Анги & Баг & Овог & Төрөл & $\begin{array}{c}\text { 3үйл, дэд } \\
\text { зуйл }\end{array}$ & $\begin{array}{c}\text { Эзлэх } \\
\text { хувь }\end{array}$ \\
\hline \multirow{2}{*}{ 1. Ойм } & 1. Шивэрс хэлбэртэн & 2 & 2 & 2 & 4 & 7 & 0.22 \\
\cline { 2 - 9 } & 2. Ойм хэлбэртэн & 3 & 3 & 11 & 18 & 42 & 1.34 \\
\hline \multirow{2}{*}{ 2. Нүигэн Үртэн } & 3. Нарстан & 1 & 1 & 2 & 5 & 13 & 0.41 \\
\cline { 2 - 9 } & 4. Гнетофит & 1 & 1 & 1 & 1 & 9 & 0.28 \\
\hline 3. Далд Үртэн & 5. Далд Үртэн & 7 & 32 & 96 & 655 & 3056 & 97.72 \\
\hline & нийт & 14 & 39 & 112 & 683 & 3127 & 100.0 \\
\hline
\end{tabular}

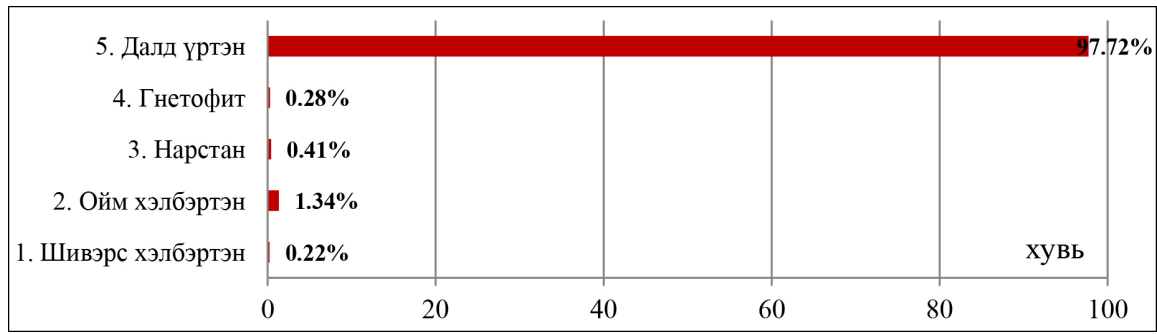

Зураг 2. Монгол орны гуурст ургамльн олон янз байдал, тэдгээрийн эзлэх хувь

Далд үртний хүрээ буюу цэцэгт талт (2449 зүйлтэй) хэмээн 2 ангид ялгадаг ургамлыг нь нэг талт (607 зүйлтэй) ба хос ба 25/75 хувийн харьцаатай юм (Хүснэгт 8).

Хүснэгт 8. Далд үрт ургамльвн зүйлийн бүрдэл, эзлэх хувь (Urgamal et al. 2014)

\begin{tabular}{|c|c|c|c|c|}
\hline Ангийн нэр & Овгийн тоо & Төрлийн тоо & Зуйлийн тоо & Эзлэх хувь \\
\hline 1. Нэг талт Үртэн & 21 & 125 & 607 & 24.78 \\
\hline 2. Хос талт үртэн & 75 & 530 & 2449 & 75.21 \\
\hline нийт & 96 & 655 & 3056 & 100.0 \\
\hline
\end{tabular}

Монгол орны гуурст ургамлын томоохон 10 овог, төрлийн зүйлийн бүрдэл доорх хүснэгтээс тодорхой харагдана (Хүснэгт 9).

Монгол орны гуурст ургамлын аймагт унаган ургамал 153 зүйл, завсрын унаган 458 зүйл, нэн ховор 133 зүйл, ховор 356 зүйл, харь ургамал 35 зүйл, хөл газрын
438 зүйл, усны ургамал 143 зүйл, үлдэц (үлдвэр) ургамал 70 зүйл, зэрлэгшиж буй таримал 47 зүйл, Улаан номонд (2013) орсон 135 зүйл, Улаан дансанд (2011) орсон 148 зүйл, CITES-ийн хавсралтанд орсон 8 зүйл тус тус ургана (хүснэгт 10). 
Хүснэгт 9. Монгол орны гуурст ургамлын 10 том овог, төрлийн зүйлийн бүрдэл, эзлэх хувь (Urgamal et al. 2014)

\begin{tabular}{lcc|lcc}
\hline \multicolumn{1}{c}{ Овгийн нэр } & $\begin{array}{c}\text { Төрлийн } \\
\text { тоо }\end{array}$ & Эзлэх хувь & \multicolumn{1}{c}{ Төрлийн нэр } & $\begin{array}{c}\text { Зүйлийн } \\
\text { тоо }\end{array}$ & Эзлэх хувь \\
\hline 1. Голгэсэртэн & 478 & 15.28 & 1. Хунчир & 132 & 4.22 \\
2. Бууриагтан & 356 & 11.38 & 2. Шарилж & 104 & 3.32 \\
3. Биелэгтэн & 259 & 8.28 & 3. Ортууз & 99 & 3.16 \\
4. Сарнайтан & 161 & 5.14 & 4. Өлөн & 92 & 2.94 \\
5. Байцаатан & 160 & 5.11 & 5. Гичгэнэ & 73 & 2.33 \\
6. Rапипсиасеае & 138 & 4.41 & 6. Багваахай & 57 & 1.82 \\
7. Өлөнтөн & 132 & 4.22 & 7. Банздоо & 53 & 1.69 \\
8. Гагадайтан & 105 & 3.35 & 8. Сонгино & 52 & 1.66 \\
9. Мажтан & 103 & 3.29 & 9. Бургас & 43 & 1.37 \\
10. Баширтан & 97 & 3.10 & 10. Хувиланги & 36 & 1.15 \\
\hline
\end{tabular}

ХУснэгт 10. Гуурст ургамлын хамгаалльн бүлгүҮдийн зүйлийн бүрдэл, эзлэх хувь (Urgamal et al. 2014)

\begin{tabular}{|c|c|c|c|c|}
\hline Гуурст ургамльн бүлгүҮд & $\begin{array}{c}\text { Овгийн } \\
\text { тоо }\end{array}$ & $\begin{array}{c}\text { Төрлийн } \\
\text { тоо }\end{array}$ & $\begin{array}{c}\text { Зүйлийн } \\
\text { тоо }\end{array}$ & $\begin{array}{c}\text { Эзлэх } \\
\text { хувь }\end{array}$ \\
\hline Унаган ургамал & 26 & 65 & 153 & 4.89 \\
\hline Завсрын унаган ургамал & 39 & 157 & 458 & 14.64 \\
\hline Нэн ховор ургамал & 56 & 108 & 133 & 4.25 \\
\hline Ховор ургамал & 64 & 211 & 356 & 11.38 \\
\hline Харь ургамал & 14 & 33 & 35 & 1.11 \\
\hline Хөл газрын ургамал & 49 & 212 & 438 & 14.00 \\
\hline Усны ургамал & 31 & 50 & 143 & 4.57 \\
\hline Үлдэи (Үлдвэр) ургамал & 21 & 36 & 70 & 0.99 \\
\hline Зэрлэгшсэн таримал ургамал & 12 & 39 & 47 & 1.50 \\
\hline Улаан номонд (2013) орсон ургамал & 49 & 103 & 135 & 4.31 \\
\hline Ургамлын Улаан дансанд (2011) орсон ургамал & 53 & 116 & 148 & 4.73 \\
\hline CITES-ийн хавсралтанд орсон ургамал & 2 & 6 & 8 & 0.25 \\
\hline
\end{tabular}

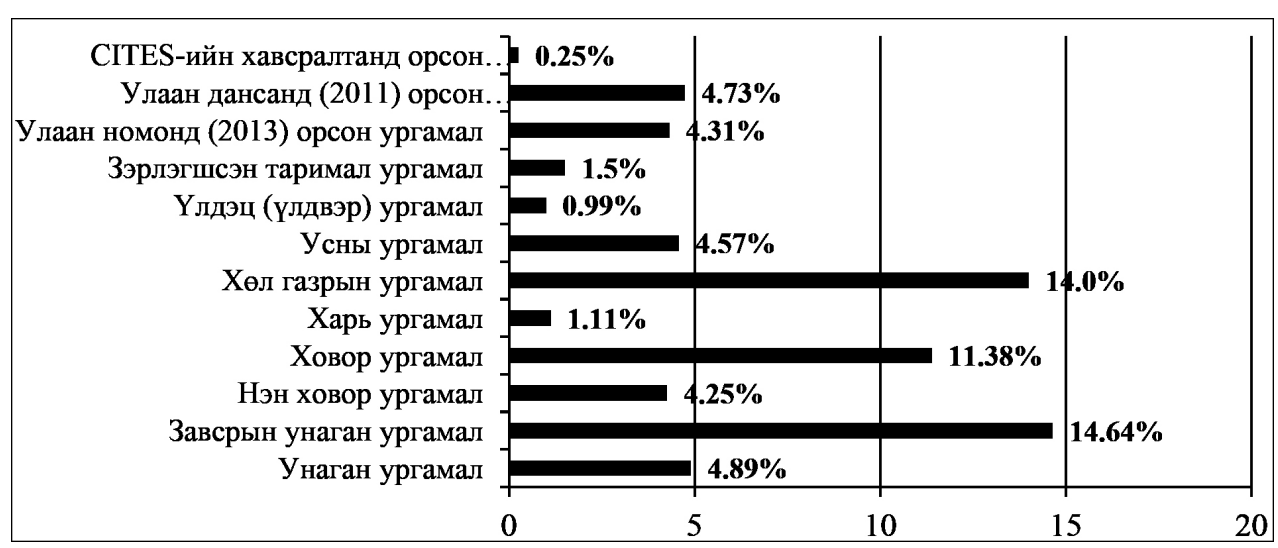

Зураг 3. Монгол орны гуурст ургамльн хамгаалльнн бүлгүүд, тэдгээрийн эзлэх хувь 
Монгол орны унаган ба завсрын унаган ургамлын томоохон 10 овгийн нэр, зүйлийн тоо, ургамлын аймагт эзлэх байр суурийг доорх хүснэгтээс тодорхой харагдана (хүснэгт 11).

Хүснэгт 11. Монгол орны унаган ба завсрын унаган ургамлын 10-н том овгийн зүйлийн бүрдэл, эзлэх хувь (Urgamal et al. 2014)

\begin{tabular}{|c|c|c|c|c|c|}
\hline \multicolumn{3}{|c|}{ Унаган ургамал } & \multicolumn{3}{|c|}{ Завсрын унаган ургамал } \\
\hline Овгийн нэр & $\begin{array}{c}\text { Зүйлийн } \\
\text { тоо }\end{array}$ & $\begin{array}{c}\text { Эзлэх } \\
\text { хувь }\end{array}$ & Овгийн нэр & $\begin{array}{c}\text { 3үйлийн } \\
\text { тоо }\end{array}$ & $\begin{array}{c}\text { Эзлэх } \\
\text { хувь }\end{array}$ \\
\hline 1. Бууриагтан & 46 & 1.47 & 1. Бууриагтан & 117 & 3.74 \\
\hline 2. Голгэсэртэн & 32 & 1.02 & 2. Голгэсэртэн & 94 & 3.00 \\
\hline 3. Сарнайтан & 17 & 0.54 & 3. Байцаатан & 30 & 0.95 \\
\hline 4. Байц̧аатан & 8 & 0.25 & 4. Биелэгтэн & 26 & 0.83 \\
\hline 5. Холтсонцэцэгттэн & 7 & 0.22 & 5. Сарнайтан & 22 & 0.70 \\
\hline 6. Мажтан & 6 & 0.19 & 6. Ночоргонотон & 18 & 0.57 \\
\hline 7. Намуутан & 6 & 0.19 & 7. Мажтан & 17 & 0.54 \\
\hline 8. Баширтан & 5 & 0.15 & 8. Холтсонцэиээтэн & 17 & 0.54 \\
\hline 9. Головстон & 3 & 0.09 & 9. Гагадайтан & 16 & 0.51 \\
\hline 10. Хорголжтон & 3 & 0.09 & 10. Майлзтан & 13 & 0.41 \\
\hline
\end{tabular}

\section{ДҮГнЭЛТ}

1. Монгол орны ургамлын аймаг, түүний олон янз байдал нь Төв Ази, Сибирь, Алтайн уулс, Дорнод Азийн бүс нутгийн флорын төлөөлөгчдөөс бүрдсэн хэдий ч унаган ба завсрын унаган ургамал цөөнгүй, олон янз байдлын хувьд ядмаг, төрөл зүйлийн тооны хувьд мөн цөөн тул цаашид бодлогын түвшинд тууштай хамгаалах нь нэн чухал юм.
2. Байгалийн болон хүний хүчин зүйлсийн, тухайлбал, мал хэт бэлчээрлэлт, уул уурхай зэрэг үйл ажиллагаа нь монгол орны ургамлын аймаг, биологийн олон янз байдалд сөрөг нөлөөлж буй өнөө үед хайрлан хамгаалбал зохих нэн ховор, ховор ургамлын жагсаалтыг нэн даруй шинэчлэн боловсруулж батлуулах нь зүйтэй.

Аиигласан бүтээлийн жагсаалт

1. Hauck, M.,Tunsberg, T., Mayrhofer, H., de Bruyn, U., Enkhtuya, O., \& Javkhlan, S. New records of lichen species from western Mongolia. Folia Cryptog. Estonica, 2013, Fasc. 50: $13-22$

2. Монголын ургамлын аймаг. 1-р дэвтэр. (Hиреrziaceae-Ephedraceae). Улаанбаатар, “Мөнхийн үсэг” хэвлэл, 2015, ISBN 978-99962-3-829-1. 219.

3. Монголын ургамлын аймаг. 10-р дэвтэр. (Согпасеае-Аріасеае). Улаанбаатар, “Бемби сан” хэвлэл, 2009, ISBN 978-99929-78-14-7. 130.

4. Монголын ургамлын аймаг. 14а дэвтэр. (Asteraceae). Улаанбаатар, “Бемби сан” хэвлэл, 2014, ISBN 978-99929-78-15-5. 277.

5. Монголын ургамлын аймаг. 17-р дэвтэр. (Сурегасеае). Улаанбаатар, “Бемби сан” хэвлэл, 2009, ISBN 978-99929-78-15-5. 137.

6. Oyuntsetseg, B. \& Urgamal, M. Vascular plants. Convention on Biological diversity the $5^{\text {th }}$ National report of Mongolia, Улаанбаатар, 2014. 21-24.

7. Өлзийхутаг, Н. Монгол орны ургамлын аймгийн тойм. Улаанбаатар, Улсын хэвлэл, 1989, 206. 
8. Urgamal, M., Oyuntsetseg, B., Nyambayar, D. \& Dulamsuren, Ch. Conspectus of the vascular plants of Mongolia. (Editors: Sanchir, Ch. \& Jamsran, Ts.). Ulaanbaatar, Mongolia. 2014, "Admon" Press. 334p.

9. Urgamal, M. \& Sanchir, Ch. An update of the family-level taxonomy of vascular plants in the Mongolian flora. Erforsch. Biol. Ress. der Mongolei. Exploration into the Biological Resources of Mongolia, vol. 13. (band 13). Martin-Luther-Universitat Halle Wittenberg, Halle (Saale), 2014, Germany. 41-48. 


\begin{abstract}
According to an overview of plant diversity in Mongolia, has 7,315 native species and infraspecific taxa of plants belonging to 1,522 genera, 392 families, 116 orders 39 classes and 19 phyla. Among them, there are 574 mushroom species in 156 genera and 56 families, 2003 algae species in 268 genera and 87 families, 1,031 lichens species in 207 genera and 63 families, 580 bryophytes species in 208 genera and 74 families, and 3127 vascular plant species in 683 genera and 112 families.

Currently according to the data, Mongolian vascular plant has 153 species (4.89\%) of endemic palnts, 458 species (14.64\%) of subendemic, 133 species $(4.25 \%)$ of very rare, 356 species $(11.38 \%)$ of rare, 35 species $(1.11 \%)$ of alien plants, 438 species $(14.0 \%)$ of antropophilus plants, 143 species (4.57\%) of aquatic plants, 70 species $(2.23 \%)$ of relict plants, 47 species $(1.50 \%)$ of wilding crops, 135 species (4.31\%) in Red Book, 148 species (4.73\%) of Red List, and 8 species $(0.25 \%)$ of in II annex of CITES.
\end{abstract}

